\title{
Desinformação sobre gênero e sexualidade e as disputas pelos limites da moralidade ${ }^{1}$
}

\section{Disinformation about gender and sexuality and the disputes over the limits of morality}

\author{
THA LES VILELA LELOa \\ Universidade de São Paulo, Departamento de Comunicações e Artes. São Paulo - SP, Brasil \\ LORENA CA M T H A S b \\ Universidade de São Paulo. Departamento de Antropologia. São Paulo - SP, Brasil
}

\section{RESUMO}

O artigo analisa a circulação da desinformação no Brasil considerando seu substrato sociocultural. Investiga histórias falsas sobre gênero e sexualidade compartilhadas em 2019, argumentando que elas se inscrevem em um terreno de disputas morais. A pesquisa coletou fake news e boatos sobre esses dois marcadores nos bancos de dados de agências de fact-checking. As características narrativas das histórias falsas foram averiguadas via análise textual qualitativa e as fontes de publicação foram identificadas por pesquisa reversa em motores de busca. Dentre os principais resultados, constata-se que ao menos 65 peças de desinformação abordaram gênero e sexualidade, a maioria delas referindo-se a eventos que pautaram a agenda pública.

Palavras-chave: Desinformação, gênero, sexualidade, moralidade

\section{ABSTRACT}

The article analyses the disinformation circulation in Brazil from its socio-cultural ground. It examines the false stories about gender and sexuality shared in 2019, arguing that they take part in a field of moral disputes. The research involved mapping fake news and rumors regarding these two markers through fact-checking agencies' databases. Narratives' characteristics of false stories were examined by qualitative textual analysis, and their publication sources were identified by reverse search in search engines. Among the main findings, it is stated that at least 65 disinformation pieces addressed gender and sexuality, most of them referring to events that guided the public agenda.

Keywords: Disinformation, gender, sexuality, morality
${ }^{1}$ Versão inicial do trabalho apresentada ao Grupo de Trabalho Comunicação, Gêneros e Sexualidades, do XXIX Encontro Anual da Compós, Universidade Federal de Mato Grosso do Sul, Campo Grande -MS, 23 a 25 de junho de 2020 .

${ }^{a}$ Pesquisador de pósdoutorado no Departamento de Comunicações e Artes da Universidade de São Paulo (CCA-USP), com bolsa da Fundação de Amparo à Pesquisa do Estado de São Paulo (Fapesp), processo $\mathrm{n}^{\circ}$ 2019/01330-0. Orcid: https:// orcid.org/0000-0002-60709332. E-mail: thales.lelo@ gmail.com

${ }^{\mathrm{b}}$ Pesquisadora de pósdoutorado no Departamento de Antropologia da Universidade de São Paulo (USP), com bolsa da Fundação de Amparo à Pesquisa do Estado de São Paulo (Fapesp), processo $n^{\circ} 2020 / 02268-4$. Orcid: https://orcid.org/00000003-1009-3880. E-mail: lorenarubiapereira@gmail.com 
${ }^{2}$ Cumpre destacar que os próprios representantes do aplicativo de mensagens WhatsApp reconheceram, em evento de jornalismo do Festival Gabo, na Colômbia (ocorrido em outubro de 2019), que na eleição brasileira de

2018 sistemas automatizados contratados por empresas fizeram disparos massivos para grupos públicos, distribuindo conteúdos políticos amiúde favoráveis ao então candidato Jair Bolsonaro - e potencialmente ferindo a legislação eleitoral vigente no Brasil (Mello, 2019).

${ }^{3}$ Pejorativamente apelidado dessa forma por críticos reacionários, o kit gay se refere a um conjunto de materiais educativos que seriam voltados

à discussão da homofobia em escolas públicas, resultado de projeto de cooperação público-governamental proposto pelo Plano Nacional de Promoção da Cidadania e dos Direitos Humanos LGBT, de 2009 (Romancini, 2018).

Todavia, diante da reação conservadora ao projeto no ano seguinte (2010), os materiais educativos nunca chegaram a ser implementados pelo Ministério da Educação. Nas eleições de 2018, o tema voltou à pauta pública como parte da estratégia difamatória de campanha de Jair Bolsonaro contra o seu principal concorrente na disputa, Fernando Haddad.

\section{INTRODUÇÃO}

$\mathrm{N}$

OS ÚLTIMOS ANOS, constata-se franca ascensão da literatura centrada em apreender as características, a infraestrutura de produção e os modos de circulação da desinformação (Egelhofer \& Lecheler, 2019; Tandoc et al., 2018). Há certo consenso de que a recente guinada nesse campo de pesquisa deriva do resultado inesperado das eleições estadunidenses de 2016 e do referendo em favor do Brexit, votado no mesmo ano no Reino Unido (Gelfert, 2018; Humprecht, 2018). As suspeitas de que esses processos decisórios foram gravemente afetados pela profusão de histórias falsas, que teriam comprometido as competências racionais dos cidadãos de tomarem decisões bem informadas (Allcott \& Gentzkow, 2017; Nelson \& Taneja, 2018), estimularam considerável atenção sobre o tema na esfera pública. Em aspecto global, desde aquele ano governos de diversos países prepararam projetos de lei e produziram campanhas coordenadas para supostamente conter os efeitos deletérios da desinformação (Tenove, 2020).

De 2018 em diante, relatórios globais anuais como o Digital News Report e o Edelman Trust Barometer passaram a incluir questões referentes à preocupação dos cidadãos com a circulação de boatos e narrativas infundadas. Desde os primeiros levantamentos sobre o tema, o Brasil vem ocupando a liderança no ranking das nações em que a população mais se diz apreensiva por não saber discernir o que é real e o que é falso na internet. Conforme a última publicação do Reuters Institute (2020), 84\% dos brasileiros se revelam aflitos com essa possibilidade (a média global é de 56\%); e, segundo o relatório mais recente da Edelman (2020), 80\% da população tem receio de que notícias falsas (fake news) sejam utilizadas como arma política. Não obstante, o relatório de 2019 do Barômetro Global da Corrupção (Pring \& Vrushi, 2019) apontou que quatro em cada cinco brasileiros disseram acreditar que conteúdos desinformativos foram disseminados para influenciar os resultados das eleições de 2018, que elegeram à Presidência da República o ex-deputado federal Jair Bolsonaro, à época membro do Partido Social Liberal (PSL).

É fato que as denúncias de instrumentalização das plataformas digitais para fins políticos ampliaram os questionamentos em torno da influência da desinformação no resultado no pleito de $2018^{2}$. Tais desconfianças se intensificaram ao se considerar, por exemplo, um estudo da consultoria Ideia Big Data/Avaaz (Avaaz, 2018) divulgado após o segundo turno das eleições: 74\% dos entrevistados disseram ter ouvido a história de que Fernando Haddad, candidato do Partido dos Trabalhadores (PT), iria implementar um kit gay ${ }^{3}$ nas escolas caso fosse eleito. Além disso, 46\% tiveram acesso ao rumor de que o ex-prefeito de São Paulo havia convidado o então deputado federal Jean Wyllys para ser Ministro 
da Educação em seu eventual governo; e outros $44 \%$ ouviram o boato de que o presidenciável teria defendido a pedofilia e o incesto em um de seus livros. Dentre os eleitores de Bolsonaro, os índices de circulação destas histórias falsas são ainda mais elevados: $85 \%$ relataram ter recebido a história do kit gay; $60 \%$ ouviram sobre o falso convite de Haddad para o Ministério da Educação; e 55\% leram as denúncias sobre as fictícias publicações criminosas do candidato do PT.

Por fim, cabe pontuar que, no caso brasileiro, assim como ocorre em outros países governados por líderes populistas da extrema-direita (Bennett \& Livingston, 2018), o próprio Bolsonaro qualifica-se como difusor sistemático de desinformações, não sendo meramente beneficiado ou vitimado por rumores compartilhados por usuários ou grupos de interesse nas mídias digitais. A título de ilustração, em entrevista para o Jornal Nacional, em 27 de agosto de 2018, ainda como candidato à Presidência, Bolsonaro mostrou às câmeras um livro intitulado Aparelho Sexual e Cia que, segundo ele, seria componente de um kit gay distribuído em bibliotecas do ensino público no país ${ }^{4}$ Já em 2019, em seu primeiro ano de mandato, um levantamento da agência de fact-checking Aos Fatos indicou que Bolsonaro fez 607 afirmações falsas ou distorcidas, que correspondem a uma média de 1,66 declarações insustentáveis por dia (Ribeiro, 2020).

Diante dessa conjuntura, este artigo pretende se debruçar sobre um aspecto até o momento menos discutido nos estudos a respeito da circulação da desinformação, a saber, o seu substrato sociocultural (Cabañes, 2020; Humprecht, 2018). Concomitantemente à profusão de pesquisas que têm retratado o Brasil como um país duramente afetado por histórias falsas e rumores (Baptista et al., 2019; Bastos dos Santos et al., 2019), há também um grande volume de trabalhos dedicados a discutir a emergência de uma guinada liberal-conservadora na América Latina (que conciliaria um pensamento neoliberal globalizado com valores autoritários), traçando inclusive suas raízes sócio-históricas (Gentile, 2018; Messenberg, 2017; Sanahuja, 2019).

Nesse sentido, busca-se argumentar que a profusão de desinformações em determinado país também decorre da afinação destas às moralidades vigentes, e não exclusivamente do descrédito da população para com as instituições que compõem o sistema democrático ou da manipulação das crenças dos cidadãos por agentes externos. Em particular, esse argumento será desenvolvido à luz da recorrência de desinformações sobre questões de gênero e sexualidade no Brasil em 2019 (primeiro ano de mandato de Bolsonaro como presidente da república), dada a sua relevância no contexto nacional ao menos desde as eleições presidenciais.

Não obstante o recrudescimento das desigualdades no período mencionado - segundo dados da Gênero e Número (Bulgarelli \& Fontgaland, 2019), 
no decorrer das eleições de 2018, mais de 50\% dos LGBT+ dizem ter sofrido algum tipo de intimidação -, constata-se a histórica persistência das assimetrias de gênero e sexualidade no Brasil. O país ocupa atualmente o $92^{\circ}$ lugar no ranking da igualdade de gênero de acordo com o Fórum Econômico Mundial (Carvalho, 2019) e figura em $68^{\circ}$ lugar na lista de nações seguras para a comunidade LGBT+, segundo o site Spartacus (2019), que elenca 197 países. Além disso, o Brasil ainda é o país que mais mata travestis e transexuais no mundo, conforme dados da Associação Nacional de Travestis e Transexuais (Benevides \& Nogueira, 2020).

Investigar a expressividade e a configuração narrativa da desinformação sobre gênero e sexualidade no Brasil permitirá, portanto, discutir as sensibilidades morais acionadas por meio das histórias falsas que incidiram nessas questões. Aventa-se a hipótese de que o potencial de circulação dessas narrativas infundadas decorre de sua vinculação ao contexto sociocultural do país, o que amplificaria, portanto, sua reverberação junto à opinião pública. Para tanto, o estudo se delineia como uma pesquisa qualitativa exploratória que intenciona, primeiramente, realizar um levantamento das desinformações sobre gênero e sexualidade que circularam no Brasil em 2019. Por meio desse mapeamento, realizar-se-á uma análise textual das narrativas coletadas (abrangendo seus temas centrais, formato de divulgação e espaços privilegiados de circulação).

O próximo tópico parte da efervescente literatura (Bennett $\&$ Livingston, 2018; Egelhofer \& Lecheler, 2019; Tandoc et al., 2018) sobre o fenômeno da desinformação para problematizar a carência de estudos dedicados a apreender seu enraizamento sociocultural e os valores morais acionados em histórias infundadas de elevado apelo entre os cidadãos. Considera-se que esse redirecionamento epistemológico é fundamental para conter certa tendência midiacêntrica e tecnicista nessa bibliografia, restaurando a dimensão propriamente comunicativa do fenômeno. Na sequência, são apresentadas conceituações operacionais para dois dos principais subgêneros de desinformação, os boatos e as fake news. O tópico subsequente revisita o conceito de moralidade, investindo em uma contextualização das disputas morais em curso no Brasil e nas normatividades hegemônicas reiteradas por representações negativas de minorias de gênero e sexualidade. Em seguida, a operacionalização metodológica do estudo e a composição de seu corpus analítico são apresentadas. Os resultados e as principais inferências obtidas pela pesquisa são discutidos logo após. Por fim, nas considerações finais, salienta-se a pertinência de examinar a produção e a circulação de desinformação em perspectiva situada, bem como indicam-se possíveis limitações e desdobramentos do artigo. 


\section{REVISÃO DE LITERATURA}

\section{$O$ contexto sociocultural da desinformação}

Em meio à recente guinada nos estudos em desinformação, diversos autores e autoras (Anderson, 2020; Andersen \& Søe, 2019; Cabañes, 2020; Marres, 2018) passaram a questionar a retomada de um paradigma de efeitos fortes da mídia subjacente à hipótese de que a desinformação seria o mal do século, capaz de prejudicar as formas de aquisição de conhecimento humano (Levy, 2017) e poluir o ambiente epistêmico (Blake-Turner, 2020). Suas consequências deletérias iriam da corrosão das competências cognitivas dos cidadãos (Brown, 2019; McKay \& Tenove, 2020) à produção de vícios intelectuais (Meyer, 2019) e ao reforço de cosmovisões extremistas e sectárias (Rini, 2017). Alguns trabalhos inclusive têm sugerido aproximações entre a difusão de histórias falsas e o contágio viral, propondo soluções ao problema que agiriam como antídotos à desinformação (Roozenbek \& Linden, 2018), a exemplo de correções promovidas por agências de fact-checking (Morris et al., 2020) e campanhas de educação para os meios (media literacy) (Jones-Jang et al., 2019).

Conforme Anderson (2020), a efervescência dessa literatura repercute uma mitologia midiacêntrica ${ }^{5}$ na qual as mídias sociais de propriedade das big techs ${ }^{6}$ assumiriam o lugar outrora atribuído ao rádio ou à televisão de distribuir em larga escala mensagens que agem sobre uma massa atomizada de indivíduos. Para o autor, a dominância de pesquisas orientadas em rastrear os efeitos coletivos dos conteúdos que circulam predominantemente nas plataformas digitais se fundamenta em uma compreensão da ação humana proposta pelas próprias plataformas. Em suas palavras, "o Facebook categoriza os usuários como sujeitos que agem, e cujas ações são influenciadas por estímulos comunicativos de curto-prazo"7 (p. 16). Nesse sentido, o endosso a essa abordagem comportamental e anti-interpretativa do processo comunicativo na bibliografia sobre desinformação estaria motivando uma desconsideração do seu necessário enraizamento sociocultural (Andersen \& Søe, 2019; Cabañes, 2020), subsumido por seus rastros digitais quantificáveis.

Restituir o componente interacional na circulação da desinformação é passo importante para reconhecer que o fenômeno em questão não se restringe a um problema de ordem meramente instrumental solucionável pelas supracitadas táticas de inoculação, ou mesmo por uma atualização nas políticas de moderação de conteúdo das plataformas (Andersen \& Søe, 2019; Cabañes, 2020; Marres, 2018). Em contraponto a um tratamento tecnicista da desinformação (que equaciona o fenômeno a um ruído que desorienta a cognição e deteriora o funcionamento da democracia), argumenta-se que a força persuasiva de histórias fraudulentas e falsos rumores decorre dos juízos morais que neles ressoam (Andersen \& Søe, 2019; Cabañes, 2020; Humprecht, 2018).
${ }^{5}$ Por midiacêntrico aqui se subentende uma tentativa de hipertrofiar o papel das mídias como único fator explicativo para quaisquer transformações sociais em curso na contemporaneidade.

${ }^{6} \mathrm{O}$ termo se refere às companhias de tecnologia do Vale do Silício, que atualmente controlam o mercado digital, com destaque para Google, Apple, Facebook, Amazon e Microsoft, também identificadas pelo acrônimo Gafam.

${ }^{7}$ No original: "Facebook categorizes its human users as subjects who act, and whose acts are influenced by shortterm communicative stimuli". Esta e demais traduções, dos autores. 


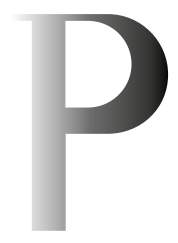

${ }^{8}$ A título de ilustração, pelo prisma da epistemologia social, Levy (2017) pontuou que boatos que discorrem sobre minorias sociais poderiam reforçar representações preconceituosas sobre seus membros.

${ }^{9}$ No original: "aspirations that ordinary Filipinos had about discipline brought about by their fears about the country's rampant disorder and criminality".

${ }^{10}$ Conforme corretamente observado por um dos pareceristas anônimos deste artigo, não foram as eleições presidenciais de 2018 a inaugurar um período de acentuada circulação de desinformações alicerçadas em gênero e sexualidade no Brasil. A título de ilustração, o processo de impeachment da ex-presidenta Dilma Rousseff, ocorrido em 2016, foi amparado por uma campanha de desinformação na qual o gênero foi acionado para desqualificar moralmente a mandatária (Piaia, 2018). Dito isso, sustentamos que, distintamente das outras eleições presidenciais do período pósredemocratização, o pleito de 2018 foi fortemente marcado pela produção de pânicos morais (Miskolci \& Campana,

2017) que reivindicavam, via desinformação, a restauração de uma moralidade conservadora em declínio. Levando em consideração que essa formação discursiva saiu vitoriosa das eleições, considerou-se pertinente observar seus desdobramentos no ano imediatamente seguinte à disputa eleitoral.
Embora a pesquisa empírica sobre o tema só recentemente esteja redirecionando suas lentes analíticas rumo a uma fundamentação axiológica e contextual da desinformação ${ }^{8}$, trabalhos como os de Humprecht (2018) e Cabañes (2020) atestam a pertinência desta abordagem. Em perspectiva internacional comparada, Humprecht (2018) detectou como na Áustria e na Alemanha os principais promotores de desinformação são sites alternativos de autoria anônima, ligados a grupos fascistas que veiculam fake news referentes aos imigrantes que residem nesses países, ao passo que nos Estado Unidos e no Reino Unido os principais assuntos das histórias falsas são as elites políticas. Já Cabañes (2020) se acercou dos imaginários antielitistas, misóginos e racistas que emanam das desinformações que circulam nas Filipinas, robustecendo a retórica populista do presidente Rodrigo Duterte. Em suas palavras, a tração dessas histórias se articula "às aspirações que os filipinos comuns tinham sobre a disciplina provocada por seus temores sobre a desordem e a criminalidade galopantes do país"9 (p. 11).

Em face do exposto, este artigo pretende averiguar a incidência de uma moralidade conservantista, especificamente ligada às questões de gênero e sexualidade, no ecossistema de desinformação brasileiro pós-eleições de $2018^{10}$. Compreendendo a desinformação como um tipo de informação que configura representações de mundo deliberadamente distorcidas capazes de reverberar nos valores partilhados por um estrato ou conjunto social (isto é, não se trata de falsificações completamente desconectadas do contexto de vida de seus interlocutores) (Fallis, 2015), sabe-se que suas formas de manifestação no ambiente digital (objeto de estudo desta pesquisa) podem ir da fabricação de notícias à manipulação de imagens (Gelfert, 2018; Tandoc et al., 2018). Portanto, em consonância a Egelhofer e Lecheler (2019), propõe-se pensar a desinformação como um conceito guarda-chuva que se ramifica em noções operacionais à pesquisa empírica. Este trabalho se centraliza em duas delas: os boatos e as fake news.

Muito embora boatos não necessariamente sejam baseados em desinformação - pois podem se referir a narrativas que sustentam relações sociais e um senso de intersubjetividade em determinada comunidade (Andersen \& Søe, 2019; Gelfert, 2018) -, àqueles que são objeto de verificação e eventualmente rotulação como falsos pela moderação de conteúdo das plataformas digitais ou por verificadores de fatos parceiros (Marres, 2018) frequentemente se enquadram nessa categoria. Amiúde publicados por perfis apócrifos com uma configuração narrativa que não emula os recursos estilísticos do jornalismo - aproveitando-se mais da arquitetura técnica das próprias plataformas para amplificarem sua visibilidade, sendo compartilhados inadvertida ou deliberadamente por outros usuários -, os boatos são componente central do ecossistema de desinformação brasileiro devido à sua capilaridade em aplicativos de mensagem e mídias 
sociais, conforme estudos precedentes, centrados no contexto das eleições de 2018, evidenciaram (Bastos dos Santos et al., 2019; Gomes \& Dourado, 2019).

Já as fake news correspondem às publicações com conteúdo deliberadamente falso ou enganoso que de fato mimetiza a linguagem jornalística - com os seus componentes típicos, incluindo título, lide e fotografias -, são veiculadas predominantemente em ambiente digital e produzidas para enganar diferentes públicos, seja com finalidades comerciais - como no caso dos clickbaits -, seja por interesses ideológicos - como nas páginas de grupos hiperpartidários que pretendem converter ou reforçar as crenças de sua audiência por meio de desinformações (Egelhofer \& Lecheler, 2019; Gelfert, 2018; Tandoc et al., 2018). Não obstante alguns autores questionarem a validade heurística do conceito por julgá-lo uma arma discursiva instrumentalizada por políticos autoritários para cercear a liberdade de expressão (Coady, 2019; HabgoodCoote, 2018), há que se considerar também a operacionalidade da noção, haja vista que não se trata de um subgênero de desinformação homólogo a noções correlatas mais estabelecidas pela literatura, a exemplo da propaganda e dos erros jornalísticos ${ }^{11}$ (Tandoc et al., 2018). Portanto, a caracterização proposta reserva o termo para conteúdos que tenham sido veiculados em páginas que exploram a autoridade jornalística para fins de desinformação, isto é, histórias e declarações falsas que não se valem dessa camuflagem jornalística estão excluídas dessa definição.

Dito isso, ao examinar fake news e boatos referentes às temáticas de gênero e sexualidade no primeiro ano do governo Bolsonaro, este trabalho não desconsidera que a arquitetura das plataformas digitais e os algoritmos de filtragem da informação e de segmentação de anúncios potencializam a confecção de conteúdos de baixo investimento, mas capazes de gerar elevadas receitas via monetização do tráfego virtual (Bakir \& McStay, 2017). Não obstante, afasta-se de explicações causais para o fenômeno da desinformação, uma vez que, dadas das condições técnicas e políticas para a sua produção em ritmo industrial, sua circulação dependerá da ressonância a valores morais compartilhados em determinado contexto sociocultural. Em outras palavras, se a infraestrutura tecnológica das mídias digitais proporciona a extração de valor por meio da quantificação de acessos independentemente do tipo de conteúdo veiculado, a concentração de usuários em um "mercado de atenção" $(\mathrm{Wu}, 2016)$ fértil em desinformação não é fruto de um efeito de distorção cognitiva que os distanciaria da verdade dos fatos (Anderson, 2020). Como será argumentado no tópico seguinte, o substrato moral no qual se assentam certas normatividades é importante fator a ser levado em consideração ao perscrutar a tração particular de histórias falsas em dada sociedade.

\footnotetext{
${ }^{11}$ Em consonância com o argumento apresentado por um dos pareceristas anônimos deste artigo, é fato que, historicamente, os erros cometidos pela imprensa não podem ser integralmente classificados como acidentais, uma vez que, em diversas circunstâncias, as organizações de mídia deliberadamente ventilaram boatos visando atender a interesses econômicos e/ou políticos avessos à ética jornalística. A título de ilustração, entre meados do século XIX e início do século XX, era comum que tabloides publicassem histórias intencionalmente fictícias para aumentarem as suas tiragens (Allcott \& Gentzkow, 2017; Tandoc et al., 2018). Por mais que concordemos que a distinção entre jornalismo profissional e desinformação não deva ser estabelecida por um critério de aproximação à verdade factual, defendemos que, em termos analíticos, é importante diferenciar a cobertura jornalística profissional da produção deliberada de desinformações, pois, no segundo caso, a própria construção narrativa se inspira na realidade social com o exclusivo propósito de enganar a audiência.
} 


\section{Vida moral, normas de gênero e sexualidade}

Considera-se a dimensão moral da vida social como eminentemente constitutiva, e não somente regulatória, das práticas cotidianas (Vandenberghe, 2015). Há um horizonte normativo que fundamenta a ação humana no mundo, fornecendo "padrões de avaliação (princípios, valores e normas) pelos quais as ações (próprias e de outros) podem ser julgadas" (Vandenberghe, 2015, p. 69). Por compor "a ordem cultural compartilhada que se institucionaliza em práticas sociais estruturadas" (Vandenberghe, 2015, p. 69), a moralidade não é propriedade de indivíduos ou grupos específicos e não se confunde com cosmovisões, sejam elas conservadoras ou progressistas, ou vieses partidários, fartamente estudados pela psicologia social como variáveis que influenciam a predisposição ou não dos indivíduos de acreditarem em desinformações (Faragó et al., 2019). Simultaneamente, por ser inerente ao processo formativo dos indivíduos, fundamentando seus juízos de valor mais ou menos conscientes sobre as situações que experimentam e as reações afetivas que deles emanam, como o rancor, a ira e a indignação (Fassin, 2008), a moralidade é componente indispensável ao agir e se materializa efetivamente nas práticas.

Dentro do campo da moralidade, as normatividades que regem gênero e sexualidade têm papel central, atuando na constituição das identidades e expressões dos sujeitos sexualizados e generificados. Elas são responsáveis por fundamentar as convenções socioculturais que perpassam esses marcadores, estabelecendo normas e princípios morais que são disputados e reiterados. Partindo da premissa de que desinformações ressoam valores morais, é de suma importância compreender como as normas em torno de gênero e sexualidade se constituem e figuram em histórias falsas acerca dessas temáticas.

Conforme Butler (1990), as normatividades em torno de gênero e sexualidade se instituem em meio ao universo contencioso da moralidade, buscando estabelecer uma coerência entre as identidades de gênero e as expressões da sexualidade que passam a ser aludidas e reiteradas no cotidiano. Nos termos da autora, essas normas socioculturais possuem um modus operandi particular, atuando a partir da prescrição e interdição de determinadas condutas e papéis. Por conseguinte, elas agem por meio de vetores de aprovação e valoração e de sanção e punição, estabelecendo os limites da própria moralidade. Para Butler (2004), as normatividades se constituem mediante seu polo oposto, criando um campo de abjeções que estipula as fronteiras entre o moralmente aceitável e o inaceitável. As ameaças às normas fundam seu exterior constitutivo, aludido e rechaçado na produção simbólica do gênero e da sexualidade.

A interseção da moralidade acerca de gênero e sexualidade institui um conjunto de valores e práticas sancionadas socialmente. Similarmente ao gênero, 
a sexualidade se fundamenta em meio a um sistema de desigualdades verticais, estabelecido em uma pirâmide de valorações e sanções. Rubin (1993) apresenta a ideia de "sistema hierárquico da sexualidade", a fim de evidenciar como funcionam os enquadramentos punitivos e de controles formais e informais que recaem sobre esse sistema. Segundo a autora, existe uma escala simbólica que determina o status e o valor sociocultural dos comportamentos e expressões erótico-sexuais, constituído de forma piramidal: no topo permanecem as práticas sancionadas, como os relacionamentos monogâmicos heterossexuais, e na base se localizam as perversões, tais como práticas homossexuais e troca de sexo por dinheiro. Na sexualidade, bem como no gênero, é o embate entre prescrições e proibições que determina os valores morais e a atribuição de status.

Tanto o sistema de estratificação de gênero quanto as hierarquias da sexualidade não são nem monolíticos, nem imutáveis. Como propõem Butler (2004) e Rubin (1993), o gênero e a sexualidade se instituem em meio a processos sócio-históricos sujeitos a mudanças. Esse campo das normatividades, que corresponde à afirmação da moralidade hegemônica, passa a ser alvo de disputa em momentos de grande estresse social e transformações sociopolíticas, reverberando em pânicos morais que tentam reinstituir e recolocar os limites da vida social também em termos de gênero e sexualidade por meio da reconstrução de restrições e sanções (Carrara, 2015). Os pânicos morais, segundo Carrara (2015), voltam-se predominantemente a grupos ou práticas minoritárias, alargando o terreno das perversões que devem ser rechaçadas do corpo social. $\mathrm{O}$ autor afirma que são propriamente pessoas homossexuais e transexuais, bem como o conjunto de mulheres que não reproduzem as marcas normativas do gênero e da sexualidade, o principal alvo dessa histeria moralizante. Esses sujeitos são tomados como um exterior constitutivo abjeto que, por sua vez, ajuda a reafirmar a importância das normas para a manutenção das hierarquias morais.

O contexto brasileiro contemporâneo é marcado por esses pânicos morais (Carrara, 2015; Leite, 2019; Miskolci \& Campana, 2017), sobretudo aqueles voltados ao gênero e à sexualidade. Os pânicos morais atuais são considerados fruto de dois fenômenos principais. Em primeira instância, emergem junto à expansão do neoconservadorismo no Brasil, que desponta na esfera pública com as manifestações ocorridas em 2013, conhecidas como Jornadas de Junho, e se assenta durante o ciclo de protestos iniciados em 2014 (Tatagiba, 2014), que culminam na eleição de Bolsonaro à Presidência da República. O neoconservadorismo tem como ideias-força a defesa da família tradicional, do conservantismo moral, da religião e do nacionalismo (Messenberg, 2017). Conforme Leite (2019), dentre os componentes do novo conservadorismo nacional, destaca-se a reafirmação das normas de gênero e sexualidade, 
${ }^{12}$ Fundada em 2015, configurase atualmente como uma das principais organizações de checagem desvinculadas dos conglomerados de mídia.

${ }^{13}$ Inaugurado em 2018 como uma coalização de veículos do Grupo Globo.

${ }^{14}$ Canal independente que, desde 2013, verifica exclusivamente conteúdos suspeitos compartilhados em redes sociais e aplicativos de mensagem. buscando reestabelecer os papéis sociais no seio da família e da nação, combatendo as identidades que supostamente estariam corroendo os valores tradicionais. Em segunda instância, os pânicos morais são acompanhados das disputas contra a "ideologia de gênero" (Miskolci \& Campana, 2017), que afloram em concomitância com o neoconservadorismo brasileiro. Essa frente de combate simbólico advoga em favor de um modelo heteronormativo de família e contra o avanço de direitos sexuais e reprodutivos, buscando acentuar, conforme Leite (2019), a necessidade de se reestabelecer os limites do campo moral que rege gênero e sexualidade.

Tal conjuntura, que expressa um intenso processo de debate simbólico e moral, associa-se à formulação das normatividades em torno de gênero e sexualidade, revelando o pano de fundo da circulação de desinformações sobre essas temáticas no ano de 2019. Faz-se premente compreender, portanto, como as histórias falsas participam desse campo contencioso.

\section{DESENHO METODOLÓGICO}

Em consonância com investigações empíricas precedentes, que averiguaram a produção e circulação da desinformação (Allcott \& Gentzkow, 2017; Humprecht, 2018), o corpus desta pesquisa foi estruturado com base em histórias falsas sobre gênero e sexualidade integralmente desmascaradas por três das principais iniciativas de fact-checking em atividade no Brasil, a saber, a agência Lupa ${ }^{12}$, o núcleo Fato ou Fake ${ }^{13}$ e o site Boatos.org ${ }^{14}$.

A coleta e codificação dos dados foram feitas manualmente por ambos os pesquisadores a partir do arquivo de checagens referente a 2019, disponibilizado por cada iniciativa em seus respectivos sites. Foram consideradas somente publicações que se referissem às questões de gênero e sexualidade e que tivessem sido motivadas por desinformações veiculadas na web, excluindo, portanto, declarações de autoridades públicas, sujeitas a graus variados de imprecisão e não necessariamente fundamentadas em boatos e fake news.

A decisão de incluir ou não determinado item no corpus decorreu de discussão conjunta entre os pesquisadores. Eventuais discrepâncias no processo de codificação motivaram a sua interrupção para a devida resolução da divergência. Levando em conta que o resultado da coleta não traduz a totalidade das históricas inverídicas sobre gênero e sexualidade que circularam no primeiro ano do governo Bolsonaro, espera-se que a diversidade de veículos contemplados possibilite abranger uma quantidade mais expressiva de conteúdos a serem examinados, haja vista que o Boatos.org produziu 1.008 verificações em 2019; a agência Lupa, 497; e o Fato ou Fake, 231. 
Excluídas publicações em duplicata (isto é, verificações de uma mesma história produzida por mais de uma das três agências), chegou-se a um total de 65 boatos e fake news sobre gênero e sexualidade verificados em 2019. Isto é, a cada mês, em média 5,41 desinformações sobre estas temáticas circularam no ambiente digital, conforme indicado na Figura 1.

\section{Figura 1}

Desinformações sobre gênero e sexualidade em 2019

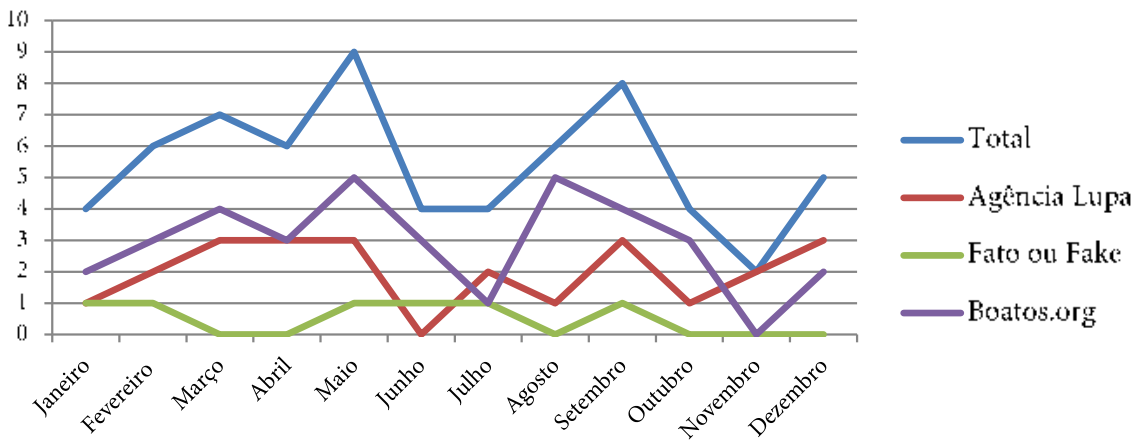

Nota. Elaborada pelos autores.

Os dados coletados foram tratados via análise textual qualitativa aberta em duas etapas. Em um primeiro momento, buscou-se delimitar o formato de circulação da publicação. As fontes das checagens foram classificadas como boato ou fake news a partir de informações disponibilizadas pelas próprias agências de fact-checking em suas correções. Complementarmente, foram examinados dois elementos das 65 narrativas que compõem o corpus de pesquisa: os principais agentes mencionados e a vinculação ou não da história a acontecimentos sociais relevantes ao contexto sociocultural brasileiro, de forma a tecer inferências sobre as moralidades em disputa nessas tramas.

Já a segunda etapa da pesquisa consistiu em localizar fontes de publicação das fake news sobre gênero e sexualidade, visando rastrear alguns dos sites em que circularam. O objetivo era entender como as páginas apócrifas encontradas se autodefinem - como canais jornalísticos ou espaços de opinião e análise, por exemplo -, sua eventual filiação a determinadas posições ideológicas e o estilo jornalístico adotado na publicação - se o texto se apresentava, por exemplo, como notícia (contendo título, subtítulo, fotografia com legendas e texto principal com lide) ou como nota (acompanhada de título e fotografia somente). A pesquisa reversa pelas fontes foi realizada a partir de motores de busca digitais, 
considerando títulos, palavras-chave e data de publicação das desinformações classificadas como fake news na primeira etapa do estudo. Complementarmente, a partir de recentes levantamentos feitos pelas agências Aos Fatos (Nalon \& Ribeiro, 2020) e Pública (Rudnitzki \& Scofield, 2020), e pelo Coletivo Bereia (Costa, 2020), realizou-se pesquisa direta em dezenove páginas rotuladas como apócrifas (Tabela 1), visando identificar quais delas publicaram as notícias falsas que compõem o corpus desta investigação.

\section{Tabela 1}

Lista de páginas de desinformação analisadas

\begin{tabular}{ll} 
Site & Link \\
\hline Jornal da Cidade Online & https://www.jornaldacidadeonline.com.br/ \\
\hline Senso Incomum & https://sensoincomum.org/ \\
\hline Gazeta Brasil & https://gazetabrasil.com.br/ \\
\hline Agora Paraná & https://www.agoraparana.com.br/ \\
Conexão Política & https://conexaopolitica.com.br/ \\
\hline Jornal 21 Brasil & https://www.jornal21brasil.com.br/ \\
CPAD News & http://www.cpadnews.com.br/ \\
\hline Gospel + & https://gospelmais.com.br/ \\
Gospel Prime & https://www.gospelprime.com.br/ \\
Pleno.News & https://pleno.news/ \\
Renova Mídia & https://renovamidia.com.br/ \\
Terça Livre & https://tercalivre.com.br/ \\
Revista Oeste & https://revistaoeste.com/ \\
\hline Estudos Nacionais & https://www.estudosnacionais.com/ \\
\hline Agência Caneta & http://www.caneta.org/ \\
\hline Brasil Sem Medo & https://brasilsemmedo.com/ \\
Conservadorismo do Brasil & https://conservadorismodobrasil.com.br/ \\
Editorial MBC & https://editorialmbc.com.br/ \\
Mídia Sem Máscara & https://midiasemmascara.net/ \\
\hline Nota. Elaborado pelos autores. Apesar de ter sido incluída na listagem inicial, a página do Notícia Brasil Online já não \\
está mais disponível e por isto não foi possivel considerá-la na análise.
\end{tabular}

Para compreender como as páginas que compartilharam histórias infundadas se autodefinem, foram consultadas as seções "Sobre nós" de cada site, portal ou blog considerado. Por fim, os dados foram sistematizados a fim de compreender quais são os formatos típicos de publicação das fake news sobre gênero e sexualidade que mais circularam em 2019, quais são seus canais de difusão predominantes e quais sensibilidades morais elas intencionam acionar em seu público receptor. 


\section{RESULTADOS}

Formatos e características das desinformações sobre gênero e sexualidade

Dentre as 65 peças desinformativas sobre gênero e sexualidade compartilhadas em 2019 no Brasil, a maior parte circulou em forma de boatos (41), com configuração típica de postagens em redes sociais ou aplicativos de mensagem: publicação com discursos apaixonados, destaques em caps lock, imagens adulteradas de forma amadora, erros ortográficos e uso de palavras de baixo calão. Outras 24 foram difundidas como fake news e verificadas pelas agências e núcleos de fact-checking a partir de sua distribuição em páginas apócrifas (Figura 2). Segmentando os dados pelas iniciativas consideradas, constata-se que Lupa verificou oito histórias com configuração jornalística e outras dezesseis em formato de boato; Fato ou Fake examinou duas na primeira categoria e quatro na segunda; e Boatos.org analisou 14 e 21, respectivamente.

\section{Figura 2}

Formatos das desinformações sobre gênero e sexualidade em 2019

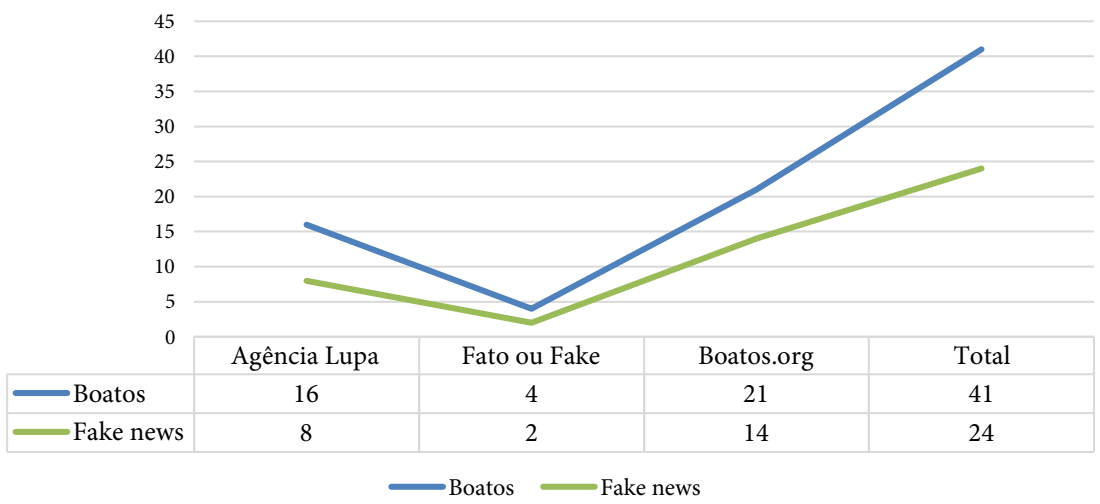

Nota. Elaborada pelos autores.

Ao examinar os conteúdos das peças de desinformação (Figura 3), percebe-se que a maior parcela deles fomentava denúncias contra políticos e partidos ligados à esquerda, acusados de corromper os valores da família tradicional. Dos quatorze conteúdos que se enquadram nessa categoria, cinco mencionam projetos de políticos da esquerda julgados moralmente reprováveis, a exemplo do Projeto de Lei 3.369/2015, de autoria do deputado federal Orlando Silva (PCdoB), que propunha instituir o estatuto das famílias do século XXI, reconhecendo formas de união diversas do modelo nuclear heteronormativo. Ao menos três diferentes narrativas infundadas sobre o assunto foram publicadas entre a data em que 
o projeto seria discutido pela Comissão de Direitos Humanos e Minorias da Câmara dos Deputados (21 de agosto de 2019) e o início de dezembro, todas elas acusando o documento de normalizar o incesto, a poligamia e a pedofilia. À época em que seria levado à votação em plenário, o projeto inclusive foi retirado da pauta em função das histórias falsas que circularam a seu respeito, alavancadas, especificamente, por deputados do PSL (Barbosa, 2019). Há também uma repetição de conteúdos que associam membros da esquerda a práticas consideradas execráveis, contraditórias e mesmo criminosas, como em manchete que afirma que a deputada federal Maria do Rosário (PT) teria defendido a descriminalização da pedofilia, ou em publicação que sustenta que o deputado federal Glauber Braga (PSOL) teria agredido a jornalista Patrícia Lélis.

\section{Figura 3}

Assuntos das desinformações sobre gênero e sexualidade em 2019

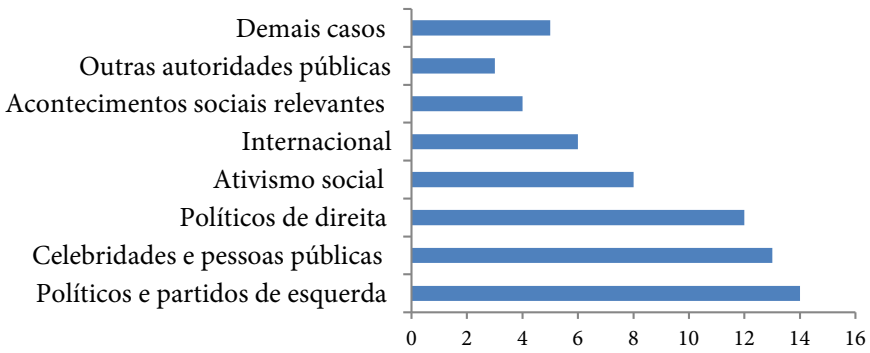

Nota. Elaborada pelos autores.

${ }^{15}$ A notícia falsa assume um tom de denúncia ao se basear na defesa feita pelo cantor, em 2018, da peça $O$ Evangelho segundo Jesus, Rainha do Céu.

${ }^{16}$ Essa desinformação passou a circular logo após o influenciador ter adquirido 14 mil livros com temática LGBT+ para serem distribuídos na Bienal do Livro do Rio de Janeiro, em resposta à decisão do ex-prefeito Marcelo Crivella de censurar exemplares da HQ Vingadores: A cruzada das Crianças, que estava sendo comercializada no evento.
Em segundo lugar (treze recorrências) se encontram textos que relacionam celebridades e pessoas públicas a falsos acontecimentos. Dentre eles, há histórias que insinuam um complô entre artistas e a mídia para deteriorar o cimento moral da família tradicional, a exemplo das narrativas que declaram que a cantora Pabllo Vittar apresentaria um programa infantil na TV Globo intitulado TV Criança Gay; que o cantor Johnny Hooker seria atração no Criança Esperança de $2019^{15}$; ou que o youtuber Felipe Neto teria incentivado crianças a acessarem fóruns de pedofilia em seu canal ${ }^{16}$. Outras publicações nessa categoria incluem materiais que legitimam formas de violência contra a mulher, inocentando os famosos envolvidos nos casos, como as insinuações de que a jovem que acusou o jogador Neymar de estupro, em maio de 2019, seria uma pessoa mal-intencionada; ou em texto que dá a entender que a ex-esposa do goleiro Jean, que atuava até dezembro de 2019 no São Paulo Futebol Clube, havia sido agredida pelo marido por ter enviado fotos íntimas para outros homens pelo WhatsApp. 
Em terceiro lugar (doze conteúdos) no catálogo de peças de desinformação sobre gênero e sexualidade que circularam em mídias digitais em 2019, estão textos sobre autoridades públicas conhecidas por suas posições abertamente reacionárias. Nesse caso, há predominância de publicações que se referem, em tom recriminatório ou irônico, a falsas declarações da atual ministra da Família, Mulher e Direitos Humanos, Damares Alves. Foram seis menções à pastora evangélica, como em história que propunha que ela iria revogar a Lei Maria da Penha; em outra que dizia que ela teria visitado o "Vale dos Homossexuais" no inferno; e ainda em publicação que alegava que ela havia criado um projeto para limitar o sexo somente para procriação. $\mathrm{O}$ atual presidente da república e sua família também são protagonistas de cinco desinformações, como em material, veiculado logo no início de 2019, que anunciava que Bolsonaro iria decretar o fim do Carnaval e da Parada Gay.

Conteúdos falsos que repreendem o ativismo social (e especificamente de grupos à esquerda) ocuparam o quarto lugar do corpus (oito casos). Quatro dessas histórias ventilaram acusações contra as universidades públicas no mesmo período em que o ex-ministro da Educação, Abraham Weintraub, insultava tais instituições e realizava um contingenciamento de $30 \%$ em suas verbas ("MEC Mira UnB, UFF e UFBA", 2019). Os protestos decorrentes destas ações do governo federal, protagonizados pelos estudantes, motivaram publicações que relacionavam as manifestações a atividades libidinosas e imorais conforme a cosmovisão conservantista, a exemplo de diversas montagens com imagens de alunos e alunas nus e texto que asseverava que os jovens teriam criado um "ateliê de arte anal" em uma universidade.

Nessa relação de histórias falsas ligadas às questões de gênero e sexualidade, foram identificados, em menor recorrência, materiais que denunciam práticas sexuais e expressões de gênero não normativas em outros países (seis textos), distorções de acontecimentos sociais que motivaram ações reacionárias ${ }^{17}$ (quatro ocorrências), denúncias de que outras autoridades públicas estariam estimulando formas de "perversão sexual" (três casos) e conteúdos mais difusos sobre a temática (cinco textos), que reforçam uma heterossexualidade compulsória, como no caso de falso estudo que teria assegurado que homens que apreciam sexo anal com suas parceiras teriam "inclinações" homossexuais.

Em vista dos dados supramencionados, é possível sustentar que a maior parcela das peças de desinformação sobre gênero e sexualidade consideradas neste estudo se refere a acontecimentos sociais relevantes ao contexto sociopolítico nacional ( 40 de 65 , ou $69 \%$ do total). Essa predominância aponta para dois fenômenos distintos: por um lado, demonstra a relevância, para a sociedade brasileira, dessas temáticas, que se acirram como elementos de
${ }^{17} \mathrm{~A}$ exemplo de textos que insinuavam que a Bienal do Livro do Rio de Janeiro de 2019 comercializava livros impróprios para o público infantil, justificando a decisão do ex-prefeito Marcelo Crivella de censurar determinadas obras. 
tensão e inquietude nos embates sobre a "ideologia de gênero" (Miskolci \& Campana, 2017); por outro lado, revela como esses assuntos passaram a compor um quadro de pânico moral, que indica a urgência em definir e assentar os "limites da moralidade" (Rubin, 1993). Esses dois pontos se sobressaem diante dos dados que revelam os temas mais sensíveis dentre as publicações analisadas, isto é, a suposta deterioração dos valores sustentadores da família tradicional e a presumida perversão das posições e expressões de gênero e sexualidade convencionais.

Acompanhando um conjunto de disputas morais que centralizaram a conjunção entre gênero e sexualidade (Carrara, 2015), as desinformações mais recorrentes no ano de 2019 contestavam a obtenção de direitos civis por pessoas LGBT+, a exemplo de textos que associavam o projeto de lei que propunha um alargamento da noção de união afetiva na Constituição Federal à apologia ao incesto e à pedofilia, criminalizando arranjos familiares que destoam dos padrões heteronormativos. Em consonância com isso, o perigo de sublevação da família mononuclear aparece como segundo assunto mais aludido nessas narrativas, reincidindo em histórias sobre celebridades do universo LGBT+ que assumiriam o posto de apresentadoras de programas infantis ou atrações em shows televisionados, reforçando as ideias de perigo e ameaça historicamente associadas à homossexualidade e à transexualidade (Rubin, 1993). Enquanto a discussão sobre o projeto de lei enfoca os riscos da subversão dos papéis compulsórios atribuídos aos homens e mulheres em relacionamentos afetivo-sexuais, os rumores envolvendo celebridades enfocam danos fictícios às crianças quando expostas à ideologia de gênero.

Outro destaque na análise foram as peças de desinformação que apontaram para condutas inadequadas de mulheres, utilizando casos conhecidos de violência de gênero para discernir os bons dos maus comportamentos, tal como ocorreu com a história das fotos de nudez da esposa do goleiro Jean. Como assevera Carrara (2015), essas distinções servem para a manutenção das posições sociais hegemônicas de homens e mulheres no arranjo heterossexual, reafirmando uma norma que permite sanções violentas às eventuais transgressões.

As histórias falsas enfocadas na denúncia do ativismo social se ocupavam em recriminar formas de exercício da sexualidade consideradas libertinas e depravadas, responsáveis por propagar comportamentos arriscados e contrários às moralidades hegemônicas. Esses casos convocavam uma hierarquia de valoração das expressões da sexualidade (Carrara, 2015), utilizando ações de militantes e universitários como exemplos de imoralidades. Trabalhando a partir da oposição, esses textos contrapunham um imaginário da sexualidade correta com as condutas obscenas de estudantes e militantes, que supostamente 
empregariam a nudez e a penetração anal para se expressarem. Mais uma vez se trata de narrativas que visam estabelecer os limites da moralidade, tal como aponta Rubin (1993), definindo um conjunto de práticas possíveis e sancionadas e outro de atividades condenadas e repreendidas. O sistema da sexualidade de Rubin demonstra aqui como as normas morais heteronormativas instituem classificações desiguais da sexualidade, assinalando aquelas que devem ser perseguidas, corrigidas e penalizadas.

Inferências similares foram obtidas na análise dos materiais que hipertrofiavam o conservantismo de políticos de direita de destacada expressão pública, em especial Damares Alves e Jair Bolsonaro. Ainda que em sua maioria tenham sido caracterizados por um tom irônico e recriminatório às ações desses atores, tais textos dialogam com os códigos morais aludidos anteriormente, distinguindo o exercício da sexualidade saudável daquele perigoso. À vista desse quadro, as desinformações que mencionavam uma decisão do governo federal de interditar o Carnaval e a Parada Gay remetem à decência e cautela necessárias em relação a atos supostamente libidinosos, que estariam sendo devidamente combatidos no governo Bolsonaro.

Os eixos morais das histórias falsas demonstram como elas se instituem mediante uma cosmovisão acerca de gênero e sexualidade fundada na dinâmica da interdição que, conforme Butler (1990), diz do estabelecimento dos limites entre as normatividades e seus exteriores constitutivos, construindo um conjunto de abjeções a serem repreendidas. Tais publicações ressoam a proibição sobre determinadas formas de incorporar e experimentar gênero e sexualidade, atuando como mecanismos para demonstrar e ratificar as normas sociais. Pensados em conjunto, e considerando suas principais temáticas, os textos expressam o conteúdo normativo das convenções, enfatizando seu oposto para demonstrar os perigos e as ameaças que se impõem caso essas mesmas convenções sejam subvertidas (Butler, 2004). Assim sendo, tais narrativas repercutem tanto um temor de rompimento das moralidades hegemônicas quanto um instrumento de simbolização dessas mesmas moralidades. Diante disso, cumpre analisar a formatação discursiva das publicações identificadas como fake news e seus canais de publicação, percebendo os elementos que compõem sua circulação social e ajudam a assentar sua fiabilidade.

\section{Fontes de publicação das fake news}

No que concerne especificamente às 24 peças de desinformações classificadas como fake news e publicadas em sites apócrifos, identificou-se que elas circularam em formato de notícias e notas. Cinco delas apareceram em ambos 
os formatos, sete exclusivamente como notícias e doze unicamente como notas, tendo todas sido publicadas em páginas que se autodefinem como informativas (Figura 4). Considerando o número de vezes em que as 24 fake news foram publicadas, conclui-se que elas circularam ao menos 43 vezes em formatos de notas e ao menos 32 vezes aos moldes de notícias.

\section{Figura 4}

Principais fontes de publicação das fake news sobre gênero e sexualidade em 2019

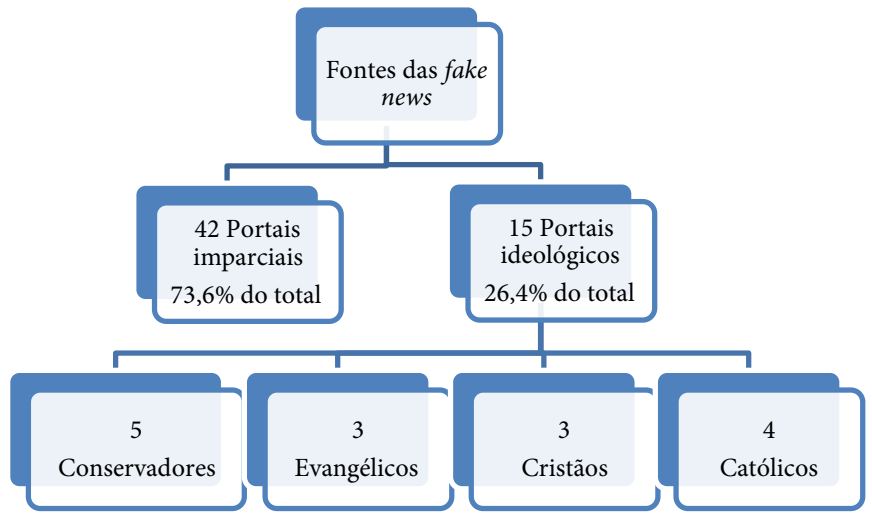

Nota. Elaborada pelos autores.

Dentre as fake news analisadas, vinte foram publicadas em mais de um portal ou site, ao passo que outras quatro apareceram em apenas um portal ou site. Dentre as 24 notícias falsas, aquelas que circularam no formato clássico de notícia apresentaram título factual em destaque, subtítulo explicativo e uma ou duas fotos com legenda, além de texto principal encabeçado por lide e composto de três ou mais parágrafos. Já as que foram publicadas em formato de nota apresentaram título factual em destaque, subtítulo explicativo, uma fotografia com legenda e texto de um parágrafo iniciado com lide.

Todas as fake news consideradas foram divulgadas em páginas na internet

${ }^{18} \mathrm{O}$ qualificador imparcial é comumente empregado na seção "Sobre nós" das 42 páginas analisadas, buscando destacar seu caráter apartidário e supostamente isento. $\mathrm{O}$ uso de tal qualificador é um recurso discursivo que visa diferenciar páginas com viés informativo daquelas com viés ideológico. autointituladas informativas ( 57 no total), das quais 42 (ou 73,6\%) se reconhecem como imparciais ${ }^{18}$, enquanto outras 15 (ou 26,4\%) estão alinhadas a alguma posição ideológica. Dentre essas últimas, cinco se consideravam conservadoras, três se diziam evangélicas, três se assumiam como cristãs e outras quatro como católicas. As páginas que mais compartilharam as desinformações foram: Pleno News (cinco histórias), Terça Livre (três histórias), Gospel Mais (três histórias) e Top Mídia News (três histórias). O primeiro desses sites se identifica como cristão; o segundo como de inclinação católica; o terceiro como evangélico, e o último como imparcial. 
As notícias falsas mais compartilhadas, que apareceram em cinco ou mais portais simultaneamente, foram:

1. O suposto projeto de lei do Congresso que legalizaria o casamento entre pais e filhos (pejorativamente denominado de lei do poliamor e publicado em dez sites). Essa história apareceu em três versões diferentes, ora apresentada como uma proposta do deputado federal Orlando Silva, ora como um projeto da ex-deputada Manuela D’Ávila, e ora como uma proposição do deputado federal Túlio Gadêlha;

2. O aparente descaso da imprensa e grupos de esquerda com as agressões sofridas por Karol Eller, youtuber bolsonarista vítima de possível ataque homofóbico (divulgado em cinco sites);

3. O rumor de que o cantor Johnny Hooker, que teria chamado Jesus de "bicha e travesti", iria se apresentar no Criança Esperança (publicado em cinco sites);

4. O caso de uma “jovem” que teria dito "estar feliz por estar grávida do pai" (veiculado em cinco portais);

5. Uma presumida cartilha distribuída pela Prefeitura de Fortaleza, que defenderia a masturbação infantil como meio de acalmar crianças (divulgada em cinco sites).

Dentre essas histórias falsas, as três primeiras foram formatadas como notícias. Já as duas últimas foram veiculadas como notas, acompanhadas de imagens e de um único parágrafo de texto.

Destaca-se que as fontes de publicação das fake news mais compartilhadas são sites autodeclarados informativos. As notícias falsas por eles veiculadas trataram exclusivamente de acontecimentos sensíveis ao universo moral nacional. Tais narrativas buscavam tecer denúncias infundadas à suposta apologia às práticas incestuosas e à pedofilia por autoridades públicas do Brasil, bem como às celebridades que divergem dos padrões normativos de gênero e sexualidade - e que, por esta razão, iriam fomentar, com a anuência de emissoras de TV, a ideologia de gênero em cadeia nacional. Ademais, uma dessas histórias procurou salientar uma atitude hipócrita da imprensa e dos movimentos de esquerda, que teriam ignorado uma violência homofóbica cometida contra uma mulher lésbica de extrema-direita. Nas entrelinhas, esta história reforçaria a tese de que a militância por direitos civis não estaria de fato preocupada em combater injustiças, mas sim em impor a ideologia de gênero. Todas as fake news apelavam à corrupção dos valores morais e à alegada degradação da instituição da família, responsabilizando atores sociais identificados como pertencentes à esquerda ou 
às minorias sociais (centralmente pessoas LGBT+) por essa situação, interpelando a audiência a se opor e enfrentar tais iniciativas.

Conclui-se que o potencial público visado por estas notícias falsas coaduna com uma cosmovisão conservantista, uma vez que tais textos visam acionar sensibilidades morais para um fim ideológico, isto é, a promoção de ideais reacionários, mobilizados discursivamente nas narrativas. Sua credibilidade fica a cargo de uma roupagem jornalística, cuidadosamente emulada com um intuito mais político (de mobilização de ações) do que econômico (de monetização pela ampliação do tráfego nos sites). Todavia, dado o fato de que as fake news sobre gênero e sexualidade contempladas neste estudo expõem frontalmente os perigos associados a uma presumida subversão da heteronormatividade - visando restituir convenções que alicerçam seu sistema axiológico (como a idealidade da família mononuclear calcada na complementaridade entre os gêneros masculino e feminino (Messenberg, 2017) - não se pode desconsiderar o fato de que elas subentendem uma partilha prévia de sentidos com seus públicos.

Por essa perspectiva, o cenário de pânico moral conformado pelos materiais aqui analisados atua menos como vetor de conversão ideológica pela via da desinformação do que como reforço de sensibilidades morais enraizadas na audiência. Em outras palavras, e levando em consideração a especificidade temática de muitos dos portais identificados na análise, as fake news observadas assumem a função de ressoar as bases de uma moral heteronormativa para um público idealmente já inclinado a ela, afirmando convenções que se supõem enfraquecidas por meio de narrativas socialmente reconhecidas e dignas de credibilidade (Rubin, 1993). Tais notícias falsas atuam como dispositivos discursivos e morais do gênero e da sexualidade, mobilizando e edificando normatividades por meio de seu conteúdo, formatação e meios de divulgação.

\section{CONSIDERAÇÕES FINAIS}

O presente estudo permitiu constatar que as peças de desinformação ligadas ao gênero e à sexualidade no Brasil se referem, em sua maioria, a temas sensíveis à sociedade brasileira, apontando como alvo preferencial supostas perversões sexuais (como o incesto e a pedofilia) e a subversão das identidades normativas de gênero (como nos casos envolvendo celebridades do universo LGBT+). Nesse sentido, sustenta-se a pertinência de examinar a produção e a circulação de desinformações tomando por referência o contexto sociocultural em que se arvoram e as disputas morais que mobilizam, transcendendo uma abordagem midiacêntrica do fenômeno. À vista disso, esse estudo destaca o campo moral em que se inscrevem as notícias falsas analisadas, concentrando-se especialmente nos limites e nas 
fronteiras desenhadas para gênero e sexualidade nessas desinformações. Salienta o reforço de moralidades compartilhadas entre fake news e sua audiência, ressoando uma cosmovisão conservantista que pretende ser ratificada e endossada ${ }^{19}$.

Apesar de os resultados obtidos oferecerem contribuições substanciais para a observação crítica da relação entre a desinformação e moralidade (em específico, ligada às questões de gênero e sexualidade), a investigação apresenta algumas limitações que merecem ser apontadas. A principal se refere ao fato de o estudo ter se baseado somente em histórias falsas detectadas por iniciativas de fact-checking, que não necessariamente correspondem a todo o volume de desinformação digital que circulou em 2019. Ainda que tal escolha metodológica tenha se inspirado na literatura sobre o tema, considera-se que esforços complementares de mapeamento (via análise de redes, por exemplo) possam ser benéficos a este tipo de investigação. Igualmente, a busca pelas fontes de publicação de histórias falsas em motores de busca é certamente prejudicada pela efemeridade desses conteúdos, que frequentemente são apagados ou modificados pelos seus criadores após terem sido desmascarados. Esse fenômeno pode impactar negativamente análises longitudinais, gerando uma defasagem na contabilização das fontes propagadoras de desinformação.

Visando impulsionar investigações afins, apontam-se como possíveis desdobramentos deste trabalho estudos focados em identificar falsas narrativas baseadas em outros marcadores sociais da diferença - como classe, raça e etnia, por exemplo -, bem como estudos de recepção capazes de perscrutar os públicos concretamente convocados e mobilizados por desinformações assentadas em disputas morais em curso em determinado contexto sociocultural. Tais investimentos possibilitariam ir além da tendência de redução da ação humana aos seus rastros digitais (Livingstone, 2018), contemplando os processos interpretativos adotados pelos sujeitos para apreenderem esse tipo de desinformações e simbolizá-las no tecido social. Por fim, também auxiliariam na compreensão das moralidades acionadas por essas narrativas inverídicas, revelando de qual maneira e por meio de quais mecanismos elas tornam as normatividades explícitas para os seus leitores. $\mathbf{M}$

\section{REFERÊNCIAS}

Allcott, H., \& Gentzkow, M. (2017). Social media and fake news in the 2016 election. Journal of Economic Perspectives, 31(2), 211-236. https://dx.doi. org/10.1257/jep.31.2.211

Andersen, J., \& Søe, S. (2019). Communicative actions we live by: The problem with fact-checking, tagging or flagging fake news: The case of Facebook.

\footnotetext{
${ }^{19}$ Ainda que os resultados apontem grupos centrais na circulação de histórias falsas sobre gênero e sexualidade, com destaque para coletivos religiosos, este estudo não objetivou analisar os interesses ou os métodos empregados por esses coletivos para produzir e compartilhar as fake news. Limitou-se à discussão da delimitação e do reforço de fronteiras morais, discussão essa que pode se beneficiar de investigações futuras que considerem a formação de grupos e redes de compartilhamento de desinformação.
} 
European Journal of Communication, 35(2), 126-139. http://dx.doi. org/10.1177/0267323119894489

Anderson, C. (2020). Fake news is not a virus: On platforms and their effects. Communication Theory, 31(1), 42-61. https://doi.org/10.1093/ct/qtaa008 Avaaz. (2018). Eleições e fake news. IDEIA Big Data. https://bityli.com/mezMI Bakir, V., \& McStay, A. (2017). Fake news and the economy of emotions: Problems, causes, solutions. Digital Journalism, 6(2), 154-175. https://dx.doi.org/10.1 080/21670811.2017.1345645

Baptista, E., Rossini, P., Oliveira, V., \& Stromer-Galley, J. (2019). A circulação da (des)informação política no WhatsApp e no Facebook. Lumina, 13(3), 29-46. https://doi.org/10.34019/1981-4070.2019.v13.28667

Barbosa, M. (2019, 21 de agosto). Estatuto das Famílias é questionado e sai da pauta para ganhar novo parecer. Congresso em Foco. https://bit.ly/2Tmauzw

Bastos dos Santos, J., Freitas, M., Aldé, A., Santos, K., \& Cunha, V. (2019). WhatsApp, política mobile e desinformação: A hidra nas eleições presidenciais de 2018. Comunicação \& Sociedade, 41(2), 307-334. https://doi. org/10.15603/2175-7755/cs.v41n2p307-334

Benevides, B., \& Nogueira, S. (2020). Dossiê dos assassinatos e da violência contra travestis e transexuais brasileiras em 2019. Expressão Popular. https://bit.ly/2TgqFOW

Bennett, W., \& Livingston, S. (2018). The disinformation order: Disruptive communication and the decline of democratic institutions. European Journal of Communication, 33(2), 122-139. https://doi. org/10.1177\%2F0267323118760317

Blake-Turner, C. (2020). Fake news, relevant alternatives, and the degradation of our epistemic environment. Inquiry. https://doi.org/10.1080/00201 74X.2020.1725623

Brown, E. (2019). Propaganda, misinformation, and the epistemic value of democracy. Critical Review, 30(3-4), 194-218. https://doi.org/10.1080/0891381 1.2018.1575007

Bulgarelli, L., \& Fontgaland, A. (2019). Violência contra LGBTs+ nos contextos eleitoral e pós-eleitoral. Gênero e Número. https://bit.ly/3yaHBoQ

Butler, J. (1990). Gender trouble: Feminism and subversion of identity. Routledge. Butler, J. (2004). Undoing gender. Routledge.

Cabañes, J. (2020). Digital disinformation and the imaginative dimension of communication. Journalism \& Mass Communication Quarterly, 97(2), 435-452. https://doi.org/10.1177/1077699020913799

Carrara, S. (2015). Moralidades, racionalidades e políticas sexuais no Brasil contemporâneo. Mana, 21(2), 323-345. https://doi.org/10.1590/0104-93132015v21n2p323 
Carvalho, M. (2019, 16 de dezembro). Brasil sobe em ranking de igualdade de gênero, mas ainda ocupa a $92^{a}$ posição. Estadão. https://bit.ly/3x7dSNq

Coady, D. (2019). The trouble with 'Fake News'. Social Epistemology Review and Reply Collective, 8(10), 40-52. https://wp.me/p1Bfg0-4w5

Costa, S. (2020, 14 de novembro). 1 ano: Sites religiosos e ativistas digitais que propagam desinformação. Bereia. https://bit.ly/3jCcI8M

Edelman. (2020). Edelman Trust Barometer 2020. https://bit.ly/3hJAFsf

Egelhofer, J., \& Lecheler, S. (2019). Fake news as a two-dimensional phenomenon: A framework and research agenda. Annals of the International Communication Association, 43(2), 97-116. https://doi.org/10.1080/23808985.2019.1602782

Fallis, D. (2015). What is disinformation? Library Trends, 63(3), 401-426. https:// doi.org/10.1353/lib.2015.0014

Faragó, L., Kende, A., \& Krekó, P. (2019). We only believe in news that we doctored ourselves: The connection between partisanship and political fake news. Social Psychology, 51(2), 77-90. https://doi.org/10.1027/1864-9335/a000391

Fassin, D. (2008). Beyond good and evil? Questioning the anthropological discomfort with morals. Anthropological Theory, 8(4), 333-344. https://doi. org/10.1177/1463499608096642

Gelfert, A. (2018). Fake news: A definition. Informal Logic, 38(1), 84-117. https:// doi.org/10.22329/il.v38i1.5068

Gentile, F. (2018). A direita brasileira em perspectiva histórica. Plural, 25(1), 92-110. https://doi.org/10.11606/issn.2176-8099.pcso.2018.149017

Gomes, W., \& Dourado, T. (2019). Fake news, um fenômeno de comunicação política entre jornalismo, política e democracia. Estudos em Jornalismo e Mídia, 16(2), 33-45. https://doi.org/10.5007/1984-6924.2019v16n2p33

Habgood-Coote, J. (2018). Stop talking about fake news! Inquiry, 62(9-10), 1033-1065. https://doi.org/10.1080/0020174X.2018.1508363

Humprecht, E. (2018). Where fake news flourishes: A comparison across four Western democracies. Information, Communication \& Society, 22(13), 1973-1988. https://doi.org/10.1080/1369118X.2018.1474241

Jones-Jang, S., Mortensen, T., \& Liu, J. (2019). Does media literacy help identification of fake news? Information literacy helps, but other literacies don't. American Behavioral Scientist, 65(2), 371-388. https://doi. org/10.1177/0002764219869406

Leite, V. (2019). "Em defesa das crianças e da família": Refletindo sobre discursos acionados por atores religiosos "conservadores" em controvérsias públicas envolvendo gênero e sexualidade. Sexualidad, Salud y Sociedad, (32), 119142. https://doi.org/10.1590/1984-6487.sess.2019.32.07.a 
Levy, N. (2017). The bad news about fake news. Social Epistemology Review and Reply Collective, 6(8), 20-36. http://wp.me/p1Bfg0-3GV

Livingstone, S. (2018). Audiences in an age of datafication: Critical questions for media research. Television \& New Media, 20(2), 170-183. https://doi. org/10.1177/1527476418811118

Marres, N. (2018). Why we can't have our facts back. Engaging Science, Technology, and Society, 4, 423-443. https://doi.org/10.17351/ests2018.188

McKay, S., \& Tenove, C. (2020). Disinformation as a threat to deliberative democracy. Political Research Quarterly. https://doi.org/10.1177/1065912920938143

MEC mira UnB, UFF e UFBA e anuncia corte de $30 \%$ da verba por "balbúrdia”. (2019, 30 de abril). Exame. https://bit.ly/2Txu37X

Mello, P. (2019, 8 de outubro). WhatsApp admite envio maciço ilegal de mensagens nas eleições de 2018. Folha de S.Paulo. https://bit.ly/3hbVld0

Messenberg, D. (2017). A direita que saiu do armário: A cosmovisão dos formadores de opinião dos manifestantes de direita brasileiros. Sociedade e Estado, 32(3), 621-647. https://doi.org/10.1590/s0102-69922017.3203004

Meyer, M. (2019). Fake news, conspiracy, and intellectual vice. Social Epistemology Review and Reply Collective, 8(10), 9-19. https://wp.me/p1Bfg0-4tp

Miskolci, R., \& Campana, M. (2017). "Ideologia de gênero": Notas para a genealogia de um pânico moral contemporâneo. Sociedade e Estado, 32(3), 725747. https://doi.org/10.1590/s0102-69922017.3203008

Morris, D., Morris, J., \& Francia, P. (2020). A fake news inoculation? Fact checkers, partisan identification, and the power of misinformation. Politics, Groups, and Identities, 8(5), 986-1005. https://doi.org/10.1080/21565503.2020.1803935

Nalon, T., \& Ribeiro, A. (2020, 21 de maio). Como sete sites lucraram com anúncios no Google ao publicar desinformação sobre a pandemia. Aos Fatos. https:// bit.ly/36fm2Yc

Nelson, J., \& Taneja, H. (2018). The small, disloyal fake news audience: The role of audience availability in fake news consumption. New Media \& Society, 20(10), 3720-3737. https://doi.org/10.1177/1461444818758715

Piaia, V. (2018). Rumores, fake news e o impeachment de Dilma Rousseff. Teoria e Cultura, 13(2), 22-39. https://doi.org/10.34019/2318-101X.2018.v13.12427

Pring, C., \& Vrushi, J. (2019). Barômetro global da corrupção: América Latina e Caribe 2019. Transparência Internacional. https://bit.ly/369bQk4

Reuters Institute. (2020). Digital news report. https://bit.ly/3jBfXNz

Ribeiro, A. (2020, 7 de dezembro). Em dois anos de governo, Bolsonaro deu ao menos três declarações falsas ou distorcidas por dia. Aos Fatos. https://bit.ly/3hn4kqQ

Rini, R. (2017). Fake news and partisan epistemology. Kennedy Institute of Ethics Journal, 27(2), 43-64. https://bit.ly/3phGMr7 
Romancini, R. (2018). Do "Kit Gay" ao "Monitor da Doutrinação": A reação conservadora no Brasil. Contracampo, 37(2), 1-22. https://doi.org/10.22409/ contracampo.v0i0.1102

Roozenbeek, J., \& Linden, S. (2018). The fake news game: Actively inoculating against the risk of misinformation. Journal of Risk Research, 22(5), 570-580. https://doi.org/10.1080/13669877.2018.1443491

Rubin, G. (1993). Thinking sex: Notes for a radical theory of the politics of sexuality. In M. Barale \& D. Halpern (Eds.), The lesbian and gay studies reader (pp. 143-179). Routledge.

Rudnitzki, E., \& Scofield, L. (2020, 16 de novembro). Página do Exército e sites governamentais ajudam desempenho de portais bolsonaristas no Google. Agência Pública. https://bit.ly/3xwthal

Sanahuja, J. (2019). La crisis de integración y el regionalismo en América Latina: Giro liberal-conservador y contestación normativa. In M. Mesa (Ed.), Ascenso del nacionalismo y el autoritarismo en el sistema internacional: anuario 2018-2019 (pp. 107-216). Ceipaz. https://bit.ly/2RSAnX5

Spartacus. (2019). Spartacus gay travel index 2019. https://bit.ly/3AvTRlR

Tandoc, E., Jr., Lim, Z., \& Ling, R. (2018). Defining “fake news". Digital Journalism, 6(2), 137-153. https://doi.org/10.1080/21670811.2017.1360143

Tatagiba, L. (2014). 1984, 1992 e 2013. Sobre ciclos de protesto e democracia no Brasil. Política e Sociedade, 13(28), 35-62. https://doi. org/10.5007/2175-7984.2014v13n28p35

Tenove, C. (2020). Protecting democracy from disinformation: Normative threats and policy responses. The International Journal of Press/Politics, 25(3), 517-537. https://doi.org/10.1177/1940161220918740

TSE diz que "kit gay" não existiu e proíbe Bolsonaro de disseminar notícia falsa. (2018, 16 de outubro). Congresso em Foco. https://bit.ly/3h8FNHf

Vandenberghe, F. (2015). A sociologia como uma filosofia prática e moral (evice-versa). Sociologias, 17(39), 60-109. https://doi.org/10.1590/15174522-017003903

Wu, T. (2016). The attention merchants: The epic scramble to get inside our heads. Vintage.

Artigo recebido em 11 de dezembro de 2020 e aprovado em 27 de abril de 2021. 